\title{
DE OPLEIDING VOLGENS HET ONTWERP VAN WET OP DE ACCOUNTANTS VOOR HET MIDDEN- EN KLEINBEDRIJF
}

\author{
door Prof. G. Diephuis
}

Het vraagstuk van de opleiding van hen, die te zijner tijd de in het wetsontwerp aangekondigde titel ,accountant voor het midden- en kleinbedrijf” mogen voeren, is een belangrijk aspect van de voorgestelde wettelijke regeling. Weliswaar zal de $\mathrm{kwaliteit}$ van de beroepsuitoefening in de eerste jaren voornamelijk worden bepaald door de "werkers van het eerste uur", i.c. degenen die via de overgangsregeling recht op de titel zullen verkrijgen, doch er mag worden aangenomen dat op wat langere termijn gezien een steeds toenemend deel van de betrokken groep zal bestaan uit personen, die anders dan via de overgangsregeling de officiële kwalificatie zullen verkrijgen. Zij zullen n.l. beschikken over het diploma dat zal worden afgegeven op grond van het daartoe door de Wet ingestelde examen, c.q. over een ander bewijsstuk waaruit eenzelfde vakbekwaamheid blijkt.

Het is de opleiding van deze „komende” categorie, waarop ik in dit artikel met name het oog heb.

Titel V van het wetsontwerp regelt de instelling van het examen. De inhoud hiervan komt in hoofdzaak hierop neer, dat minstens één maal per jaar een examen zal worden afgenomen waarvan omvang en inrichting alsmede toelatingseisen en vrijstellende eisen bij algemene maatregel van bestuur zullen worden vastgesteld. De desbetreffende artikelen vertonen sterke gelijkenis met de artikelen $71 \mathrm{t} / \mathrm{m} 73$ van de Wet op de Registeraccountants. Over de opleiding voor dit examen wordt in het wetsontwerp in het geheel niet gesproken. Dit in tegenstelling tot de Wet op de Registeraccountants, welke in artikel 1 lid 3 o.m. bepaalt, dat de Orde tot taak heeft het verzorgen van een opleiding tot registeraccountant. Aan de te creëren Raad voor Accountants voor het midden- en kleinbedrijf is kennelijk niet een dergelijke taak toebedacht.

De Memorie van Toelichting (MvT) bij het wetsontwerp verstrekt evenwel in $\$ 4$ meer bijzonderheden. Daaruit blijkt, dat de bewindslieden in overeenstemming met de conclusies van de Commissies Brands I en II van mening zijn, dat als toelatingseis voor het in te stellen examen zal gelden het bezit van het Staatspractijkdiploma voor Bedrijfsadministratie (S.P.D.) delen I en II resp. een gelijkwaardige opleiding. Het eigenlijke examen ex artikel 48 van het wetsontwerp zal zoveel mogelijk op dit S.P.D.-examen dienen aan te sluiten. Als ideale oplossing staat de bewindslieden voor ogen, dat dit examen ook in het kader van de organisatie van het Staatspractijkdiploma zal worden afgenomen.

In april 1967 is door de Staatssecretaris van Economische Zaken een werkgroep van deskundigen ingesteld, die tot taak kreeg de Staatssecretaris te adviseren omtrent de exameneisen en de organisatie van het examen. Het rapport van deze werkgroep is in november 1967 uitgebracht en inmiddels voor publicatie vrijgegeven. In de Memorie van Toelichting delen de bewindslieden mede, dat zij voornemens zijn bij het vaststellen van de exameneisen in hoofdzaak de voorstellen van deze werkgroep te volgen.

In evengenoemd rapport wordt gesteld, dat het in te stellen examen beschouwd moet worden als aan te sluiten op het volledige S.P.D.-examen. Onder erkenning

m a b blz. 226 
van de voordelen van een althans ten dele mondeling examen, opteert de werkgroep niettemin - om practische redenen - voor een voorshands geheel schriftelijk examen, dat éénmaal per jaar zal worden afgenomen. Dit examen mag niet te $z$ waar zijn; de periode waarin goede studenten dit examen moeten kunnen doorstaan na het het S.P.D.-examen te hebben afgelegd, wordt op één jaar gesteld. In het verslag van de werkgroep is een extern en een intern (d.w.z. verder gedetailleerd) examenprogramma opgenomen. Hieruit blijkt, dat kennis wordt verlangd omtrent de volgende onderwerpen:
A. beroep en functie;
B. midden-en kleinbedrijf;
C. grondslagen van de administratieve organisatie en van de controle, in het bij- zonder voor de ondernemingen in het midden- en kleinbedrijf;
D. toepassing van de fiscale wetgeving.

De werkgroep adviseert de beschikbare opleidingstijd ongeveer in de volgende verhouding over bovengenoemde kennisgebieden te verdelen: A $10 \%$; B 25\%; C $50 \% ;$ D $15 \%$.

Een suggestie van de werkgroep, welke in de MvT is overgenomen, is, dat de opleiding voor het examen zal worden verzorgd door particuliere opleidingsinstituten.

Wettelijke voorzieningen in deze, aldus de MvT, lijken niet nodig. Tenslotte is de werkgroep van mening, dat dringend behoefte bestaat aan goed lesmateriaal. Zolang dit nog niet beschikbaar is, zou in een literatuurlijst de te bestuderen stof zo exact mogelijk moeten worden aangegeven. Het advies van de werkgroep strek $t$ zich niet zo ver uit, dat hieromtrent ook suggesties worden gedaan.

Naar aanleiding van de adviezen van de Werkgroep Examenprogramma voor niet-registeraccountants zou ik enkele opmerkingen willen maken betreffende het voorgestelde examenprogramma. Ook zonder dat nadere bijzonderheden vast staan met betrekking tot lesmateriaal en literatuurlijst kan op grond van de thans bekende gegevens wel een oordeel worden gevormd over de voorgestelde opleiding. Gelet op de veelheid van onderwerpen in combinatie met de opleidingsduur van één jaar - waarbij in aanmerking is te nemen dat het hier een avondstudie betreft kan reeds bij voorbaat worden geconcludeerd, dat van enige diepgang in de opleiding geen sprake kan zijn. Herhaaldelijk wordt trouwens zowel in het werkgroeprapport als in de MvT gesteld, dat het examen niet te zwaar mag zijn en dat de exameneisen niet mogen worden overtrokken. Overigens blijkt verder uit de MvT, dat het voorgestelde examen niet pretendeert op alle gebieden een diepgaande kennis te vragen.

Zo wordt medegedeeld, dat als stelregel geldt, dat de opleiding naast de strikt noodzakelijke stof een globale oriëntatie op aangrenzend vakgebied dient te omvatten. Met betrekking tot de kennis van de administratieve organisatie wordt gesteld, dat hierin ook enige elementaire kennis van de controle (cursivering van mij) moet worden geïncorporeerd.

De conclusie, die getrokken moet worden is, dat er een belangrijke discrepantie bestaat tussen het ambiteuze programma enerzijds en de opleidingsduur anderzijds. Dit moet er toe leiden, dat de organisatoren van de t.z.t. te houden examens voor het probleem zullen worden gesteld hoe een zinvol geheel kan worden samengesteld en verder hoe als afsluiting van een oppervlakkige aanvullende opleiding 
in schriftelijk vorm examens zullen kunnen worden afgenomen. Hierbij dringt zich de vraag op hoe een dergelijk examen een waarborg kan bieden voor de deskundigheid, die het wetsontwerp beoogt te beschermen. Waar verder de inhoud van de functie van het te regelen beroep niet duidelijk omlijnd is, dreigt bovendien het gevaar dat in de toekomst het examenprogramma gaat divergeren van de functie-inhoud, die de samenstellers van het wetsontwerp voor ogen staat. Het is zeer de vraag of de voorgestelde wettelijke regeling hiertegen voldoende effectieve waarborgen biedt.

Dat de mogelijkheid van divergentie niet denkbeeldig is moge blijken uit het voor een concretisering van wetgeving hoogst verwonderlijke feit, dat de Werkgroep Examenprogramma uitgaat van een andere functie-inhoud van de categorie dienstverleners dan de bewindslieden in de MvT omschrijven en als zodanig beogen te regelen.

De MvT ziet de typische functie van de te regelen categorie als een „administratieve functie, die duidelijk is te onderscheiden van de typische functie van de registeraccountant, waar het controle-element domineert" (pag. 10, $\$ 3$; cursivering van mij). Wanneer nu de Werkgroep Examenprogramma voor niet-registeraccountants in zijn basisoverwegingen (hoofdstuk 2) stelt dat de betrokkenen „voorts een oordeel moeten kunnen geven over de aanvaardbaarheid van de uit de administratie voortvloeiende financiële verantwoording", dan heeft men hiermede een belangrijk aspect van de typische controle-functie ingevoerd. Het behoeft geen nadere adstructie, dat men met „enige elementaire kennis van de controle", nooit de deskundigheid kan creëren, die nodig is voor het afgeven van controle-oordelen over financiële verantwoordingen.

Alleen reeds hierom is de hierboven geciteerde basisoverweging van de Werkgroep onaanvaardbaar. $\mathrm{Zij}$ is bovendien strijdig met de functie-omschrijving volgens de MvT. Zoals reeds hierboven is vermeld verklaren de bewindslieden in de MvT, dat zij voornemens zijn , bij het vaststellen van de exameneisen in hoofdzaak de voorstellen van de Werkgroep te volgen". Het is noodzakelijk dat dan de door mij gewraakte toevoeging van de Werkgroep betreffende het afgeven van aanvaardbaarheidsoordelen geheel wordt geëlimineerd.

Gemeten naar de tijd is deel C: „Kennis van de grondslagen van de administratieve organisatie en de controle, in het bijzonder voor ondernemingen in het midden- en kleinbedrijf" het zwaartepunt van het programma ( $50 \%$ van de opleidingstijd). Terloops zij nog opgemerkt dat in het gedetailleerde programm m.b.t. dit onderdeel op enkele plaatsen wordt gesproken van ,middelgrote en kleine ondernemingen". Nog afgezien van de discussies rond de vraag of de term "midden- en kleinbedrijf" een juiste aanduiding is voor het werkterrein van de niet-registeraccountant, wordt door het gebruik van de term ,middelgrote en kleine ondernemingen" de indruk gewekt alsof deze synoniem is met „midden- en kleinbedrijf". Hierdoor dreigt het gevaar, dat reeds bij de eerste opzet van de opleiding, verwarring ontstaat met betrekking tot het werkterrein van de nietregisteraccountant.

Ook in de MvT wordt op enkele plaatsen, waar kennelijk gedoeld wordt op midden- en kleinbedrijf, de uitdrukking "middelgrote en kleine ondernemingen” gebruikt.

Uit het examenprogramma voor het onderhavige onderdeel wordt niet geheel duidelijk in hoeverre naast kennis van de grondslagen van de administratieve or- 
ganisatie en - meer summier - van de controle ook vaardigheid in de toepassing van deze grondslagen wordt vereist. Wel is als punt in het programma opgenomen „Typologie van de toepassing van de kennis van de administratieve organisatie en de controle in het midden- en kleinbedrijf", maar het is niet duidelijk of hiermede inderdaad wordt beoogd het aankweken van vaardigheid in het zelfstandig toepassen van kennis op concrete gevallen, b.v. via practische werkstukken (cases).

Volgens het interne programma ligt in dit deel het accent vooral op de kennis van de grondslagen van de administratieve organisatie. De controle, anders dan als element van de administratieve organisatie, zal slechts summier worden behandeld. Door mij is reeds opgemerkt dat men hieraan geen graad van deskundigheid, hoe dan ook, mag ontlenen.

Uit de historie, die voorafgaat aan de toestandkoming van het wetsontwerp, blijkt dat juist deel $\mathrm{C}$ van het programma het meest omstreden onderdeel van de thans geconcipiëerde exameneisen uitmaakt. Dit is niet verwonderlijk, omdat verschil van inzicht omtrent de functie van de groep niet-registeraccountants wel moet leiden tot verschil van inzicht in het voor deze groep te ontwerpen examenprogramma.

De eerste commissie Brands is indertijd tot het oordeel gekomen dat de te regelen groep kan worden gekenmerkt met de kwalificatie ,administratieve dienstverleners". Een goede vervulling van deze functie, aldus die Commissie, vereist dat betrokkenen hun kennis, zoals die verworven is via de volledige S.P.D.-opleiding, nog aanvullen met kennis op fiscaal gebied, op het gebied van de structurele ontwikkeling van het midden- en kleinbedrijf, op het gebied van de desbetreffende wettelijke voorzieningen in het kader van het overheidsbeleid e.d.

De meerderheid van de tweede Commissie Brands kwam tot conclusies van gelijke strekking. Dit in tegenstelling tot de minderheid van laatstgenoemde commissie die van mening was, dat een belangrijke taak van de niet-registeraccountants bestaat uit de controle van verantwoordingen door middel van het ,administratief onderzoek' en het afgeven van een oordeel hieromtrent in de vorm van ,aanvaardbaarheidsverklaringen".

Het door dit deel van de tweede Commissie Brands geadviseerde examenprogramma (zie pag. 80 en 81 van het commissierapport i.c. Bijlage 2. „Het examen voor bedrijfsaccountant") gaat dan ook qua kennisgebied veel verder dan de suggesties voor het examenprogramma van de zijde van de meerderheid. In eerstbedoeld programma komen als belangrijke punten voor "Grondslagen van de administratieve organisatie en van het administratief onderzoek” en „Grondslagen van de rapportering".

De „Werkgroep Examenprogramma voor niet-registeraccountants” bestond ten dele uit personen, die ook zitting hadden in de tweede Commissie Brands. De betrokkenen waren alle ondertekenaars van het minderheidsrapport van genoemde commissie. Het is daarom niet bevreemdend, dat het standpunt van deze minderheid inzake de functie van de niet-registeraccountant doorklinkt in het rapport van de werkgroep.

Niettemin blijft de niet-gelijkvormigheid van de functie, die de werkgroep als uitgangspunt heeft gekozen en de functie, welke de opdrachtgever, i.c. de Staatssecretaris van Economische Zaken, blijkens de MvT wil regelen, niet toelaatbaar.

Het valt op, dat voor het onderdeel B: „Kennis van het midden- en kleinbedrijf”, zowel relatief gezien ( $25 \%$ van de opleidingstijd) als, naar uit het voorgaande 
duidelijk zal zijn, absoluut gezien, een slechts geringe plaats is ingeruimd. In aanmerking nemende dat de niet-registeraccountant juist een functie ten behoeve van middenstand en kleinbedrijf dient te vervullen en gezien de specifieke problematiek van deze sector van het economisch leven, moet het als een leemte worden beschouwd, dat juist aan dit onderdeel van het programma zo weinig gewicht is toegekend.

Met betrekking tot de adviserende functie van de niet-registeraccountant in het algemeen wordt in de MvT opgemerkt dat zijn kennis buiten het zuiver administratieve vlak slechts van beperkte aard kan zijn; hij zal zich hiervan voortdurend bewust moeten zijn en moeten weten wanneer het gewenst is een specifiek deskundige in te schakelen.

Met een verwijzing naar een specifiek deskundige is naar mijn mening overigens het bezwaar van een onvoldoende kennis van de niet-registeraccountant omtrent de specifieke problematiek van het „midden- en kleinbedrijf" niet ondervangen.

Ongeacht de waarde, die het geconcipieerde programma overigens moge hebben als aanvulling op het S.P.D.-examen teneinde studerenden beter geschikt te maken voor het uitoefenen van de administratieve functie in vrij beroep, kan dit programma zeker niet worden beschouwd als een accountantsopleiding en het zal daarom geen aanspraak op een dergelijke aanduiding mogen maken. Een beschouwing van dit examenprogramma moet dan ook tot de conclusie leiden, dat de te regelen groep geen aanspraak kan maken op een wettelijk geregelde accountantstitel, ook niet zoals deze in het wetsontwerp is aangevuld tot ,accountant voor het midden- en kleinbedrijf".

Ik ben hiermede gekomen aan het vraagstuk van de juistheid van de in het wetsontwerp voorgestelde titel, waaraan elders in dit blad ongetwijfeld meer aandacht zal worden gewijd. 